\title{
LETTER TO FORUM 2000
}

\section{September 1997}

\section{Aung San Suu Kyi}

That an end entails a beginning is the beautiful aspect of the circularity of human existence. It is, of course, important that the soft perfection of harmonious roundness is not debased into a vicious cycle. There is little value to new beginnings if we simply commit the same mistakes that caused so much suffering in the past.

Many of us will view the beginning of the twenty-first century with some degree of excitement. What will the future bring? What can we make of the opportunities that were not given to our forefathers? Are we going to be weakminded and say 'Whatever will be will be' or are we going to face the challenges of what, a century ago, were unimaginable technological and social developments? And, if we choose to grapple with the problems that will surely come with the new millennium, how shall we go about it, how shall we educate ourselves and our young to cope with the unknown?

I regret very much that I am unable to be present at this conference and to learn from the thoughts and words of men and women who are concerned not just for their own immediate present but for the future of humankind. I doubt that I would be able to add much to the learned discussions that will take place in this conference. I would just like to put forward the simple suggestion that one of the greatest needs for the new millennium is the development of a generous spirit, a spirit that will create a rich diversity out of the different races and creeds of our planet.

A generous nature is a noble nature, a kind nature that is loving and giving and forgiving, a nature that rejoices in the good fortune of others and allows 
for the weaknesses of others in a true spirit of humility that recognises one's own weaknesses. It is a nature that seeks to alleviate the sufferings of others, not to aggravate them with self-righteous condemnation or ruthless aggression. It is a nature in which there is little room for jealousy or covetousness or contempt. It is a nature that is warm and caring. At this point, perhaps, I should hasten to say that I am not talking about saints, except perhaps in the sense of the definition that saints are the sinners who go on trying. I am simply talking of the kind of people who can help to make our life a little happier in spite of the unavoidable trials and tribulations of worldly existence.

As a politician working to establish democracy in a land ruled by a military junta, and as an individual who has to struggle to lead a normal life under abnormal circumstances, my appreciation for kind people with the generosity of spirit to see through to the human needs behind the unnatural existence of dissidents, such as myself, is unbounded. Such kindness and generosity have come from all over the world, not least from President Václav Havel and others present at this conference today. May I wish them all success in their endeavour to "create new structures of stability and democratic institutions that will foster individual liberties and more widespread observance of basic human rights... (and) to develop a broader, more humanistic consciousness that reflects the deep unity among peoples and embraces the plurality of values in the present world'.

I am confident that the generosity of spirit and the wisdom of the participants of this conference will lead them to the right answers. 